\title{
The Webquest as a Means of Improving the Efficiency of Students' Foreign Language Training of Ukrainian Technical Institutions of Higher Education (Beginning of the 21st Century)
}

\author{
Slyusarenko Nina \\ ORCID ID: https://orcid.org/0000-0002-9215-5936 \\ Kherson State University, Doctor of Pedagogical Sciences, Full Professor, \\ Professor Ye. Petukhov Department of Pedagogy, Psychology and Educational \\ Management of Kherson State University (Kherson, Ukraine)

\section{Soter Mariia} \\ ORCID ID: https://orcid.org/0000-0002-4626-0137 \\ Pervomaisk Branch of Admiral Makarov National University of Shipbuilding, \\ Ph.D. in Pedagogical Sciences, Lecturer, Department of Social and \\ Humanitarian Disciplines (Pervomaisk, Ukraine)
}

\begin{abstract}
The possibilities of WebQuest technology to improve the efficiency of students' foreign language training of Ukrainian technical institutions of higher education at the beginning of the XXI century have been revealed. It has been noted that the opportunity with the help of the WebQuest to involve all kinds of authentic texts (from the text to video material) with professionally-oriented issues helps to increase students' motivation to study and reach educational goals, provides the possibility to activate their cognitive activities and strengthen their desire for selfeducation. The advantages of this technology for improving students' foreign language training have been represented. The results of the questionnaire have been provided, which confirm that WebQuest technology gives an opportunity to expand students' vocabulary on a specific topic, to interest and motivate them to study a particular problem, to intensify the process of studying professional-oriented terminology, to develop students' foreignlanguage, lexical and socio-cultural competence.

Keywords: WebQuest technology, Internet resources, students' foreign language training, Ukrainian technical institutions of higher education.

Introduction. High-quality foreign language training is one of the challenges that sharply face technical institutions of higher education in Ukraine at the beginning of the XXI century. Considering the importance of foreign language training, it should be noted that nowadays such training is the key to full professional realization of a specialist in both domestic and international labour markets. In particular, it is directly related to engineering specialists. However, there are a number of problems that slow this process down and, in some cases, hinder it completely.
\end{abstract}

There are such problems [9, p. 189], for example, as significantly different 
students' level of foreign language training after school (the contingent of technical institutions of higher education in Ukraine, as a rule, covers graduates of rural and urban schools, general and specialized schools with in-depth study of some subjects) and, as a consequence, groups are formed with unequal level of foreign language proficiency, thus, students' level of knowledge usually ranges from the level of foreign language proficiency A 1 (Beginner (Basic), Elementary) to B 2 (Upper Intermediate); insufficient number of credits and, consequently, the number of classroom hours allocated in the technical institution of higher education for foreign language learning by students (it is usually two hours a week (one lesson) for one discipline in the first and second, less often in the upper courses); moreover, quite often such language courses as, for example, "Foreign Language", "English", "English for Specific Purposes" are studied by students of technical majors with a year pause, however, it is deviation from the principle of continuity and consistency in the educational process; insufficient, limited material and technical support of educational classrooms, within which foreign language training is carried out, which complicates the introduction into the educational process of the latest technologies and teaching tools, and many others.

Therefore, the problem of qualitative foreign language training of future specialists of technical majors requires urgent steps to solve it, as the full functioning of specialists both within the state and abroad depends on it. Furthermore, it is also related to the versatility of the language, as foreign language proficiency is a necessity for any specialist, regardless of major, direction or profile. This is especially true for those professionals whose activity is related to the regular professional interaction with colleagues. Such interaction with co-workers can influence not only the equipment integrity, but in some cases, people's lives. For example, language misunderstandings (both in native and foreign languages) can lead to serious damage, accidents and even catastrophes. Thus, it can be established that the level of language training in higher education depends on such important processes as: socialization of the future specialists, their professional self-realization, adaptation to the new challenges of modern society, including: life-long learning, academic and professional international mobility, cooperation in educational, scientific, industrial and other fields with domestic and foreign partners.

Considering all the above-mentioned issues that have been faced with the improvement of students' foreign language training of technical higher education institutions of Ukraine at 
the beginning of the 21 st century, there is an urgent need to find new effective ways to increase its level.

Problem statement. A significant reduction of classroom hours, increase of self-study hours for students of technical majors, as well as the intensification of the usage of Internet resources through various technical devices (for example, computers, laptops, tablets, mobile phones, etc.) have prompted the search of new technologies that combine the creative character, the possibility to implement them during the independent work at any convenient time for students. A WebQuest technology is an example of such educational tool. It was developed by Bernie Dodge together with Tom March (San Diego State University, USA). By B. Dodge's definition, a WebQuest is "an inquiry-oriented activity in which some or all of the information that learners interact with comes from resources on the Internet". The scientist also states that a WebQuest can be "optionally supplemented with videoconferencing" [8].

Thus, the solution of the above-mentioned problems dictates the urgent need to improve the efficiency of students' foreign language training of Ukrainian technical institutions of higher education, in particular through the introduction of a WebQuest technology.

The materials and the results of the research. It should be noted that in Ukraine the study of the experience of integrating the WebQuest technology into the educational process began at the beginning of the 21st century. In the research of Ukrainian scientists, a WebQuest technology is considered as a component of information technologies, multimedia technologies, interactive technologies, project technologies, etc.

O. Hniedkova identifies a WebQuest as a problematic task with elements of a roleplaying game for which information resources of the Internet are used; scenario of organizing students' project activities on any topic using Internet resources [1, p. 142]. While L. Savchenko singles out a WebQuest technology as a set of methods and techniques for organizing research using Internet resources [7, p. 70]. It is necessary to underline that during step-by-step work of completing a WebQuest, there is a constant interactive feedback among all subjects of the educational process (students and educators) at all stages of its completion, which gives an opportunity to ensure full subject-to-subject interaction.

As previously noted, it is not possible to fulfil a WebQuest without the inclusion of Internet resources. As I. Drobit and N. Rak emphasis, involvement in the educational process of information resources of the network gives the possibility to form reading skills, using directly 
authentic materials of different level of complexity; to improve listening comprehension skills with the help of authentic audio or video texts; to improve writing skills; to replenish the vocabulary with words of a modern foreign language; to get acquainted with linguistic and socio-cultural information; to form a stable motivation of students' foreign language activities [2, p. 108]. Thus, we can say that the implementation of information resources with the support and under the guidance of an educator promotes the formation of foreign language competence in listening, reading, writing, lexical competence, socio-cultural and professionally oriented competence, which greatly intensify their language training.

O. Oliinychenko notes that the main advantage of using a WebQuest technology is the focus on autonomy of learning, stimulation of creative thinking, students' involvement in the evaluation of their results and the results of their colleagues [5, p. 893]. V. Krasnopolskyi brings into focus that the involvement of a WebQuest technology in the educational process will give an opportunity to implement both general and methodical principles of learning foreign languages: the principle of interactivity (learning, immersed in communication, which creates conditions for the development of teamwork skills); the principle of autonomy, which is realized in the ability to independently manage their activities; the principle of authenticity, which involves the usage of a variety of authentic information, etc. [4, p. 98]. It should be noted that the opportunity with the help of the WebQuest to involve all kinds of authentic texts (from the text to video material) with professionally-oriented issues helps to increase students' motivation to study and reach educational goals, provides the possibility to activate their cognitive activities and strengthen their desire for self-education.

Bernie Dodge offers such components of a WebQuest as: introduction (the stages of the WebQuest are established and background information on its implementation is provided); representation of the task to be accomplished in the framework of the WebQuest and description of the process to be completed within the WebQuest (the process description should include clearly described steps); providing a set of information sources that are necessary for the task; instructions on the correct organization of the information received; conclusion [8].

Taking in consideration the above mentioned material, it is important to notice that to improve students' level of language training in the educational process of Pervomaisk Branch of Admiral Makarov National University of Shipbuilding during the practical training of fulltime mode of study at the first (bachelor) level of higher education in such educational programs 
as "Thermal Power Engineering", "Engineering Mechanic" and "Internal combustion engines" is used WebQuests.

As an example of using WebQuests we would like to propose the WebQuest "Health and safety", that was designed to organize students' independent work in order to systematize previously learned foreign language material on the topic that was intended future engineers to fulfil a set of tasks. The final aim of the WebQuest was to develop recommendations "Ways to ensure workplace safety for engineers" and represent them. The purpose of this WebQuest was 1) to deepen and broaden students' knowledge concerning the types of risks for engineers in the workplace, protective clothing and equipment and their use by engineers to perform all kinds of work; measures to be taken by engineers to ensure their own safety before, during and after work; 2) to develop foreign language competence in reading, writing, lexical competence, sociocultural and professionally oriented competence; 3 ) to teach respect and tolerance for other people.

The WebQuest combined three interrelated and interdependent stages. The first stage involved the division of students into groups (group A, group B and group C), the task for the first group A was to represent the types of risks for engineers in the workplace through the offered by the educator Internet websites; the task for the second group B was to describe protective clothing and equipment and their use by engineers to perform all kinds of work through the offered by the educator Internet websites; the task for the third group $\mathrm{C}$ was to characterise measures to be taken by engineers to ensure their own safety before, during and after work through the offered by the educator Internet websites. During the second stage, students of groups A, B and C had to organize the selected material and represent it as recommendations. During the third stage, students of groups A, B and C were required to present the material for each group. Before starting work, the educator explained in detail all steps of fulfilment the WebQuest, noted the need for accuracy of written tasks performance (during the development of recommendations "Ways to ensure workplace safety for engineers") and their oral representation, pointed out the indicators that would be evaluated upon completion of the WebQuest, including the quality of information and facts provided in the recommendations, creativity in presenting recommendations to groups, students' interaction in the group and the contribution of each member to achieve the end result. 


\section{Examples of Internet resources for the WebQuest fulfilment}

\begin{tabular}{|c|c|c|}
\hline No & Tasks for groups: & Internet resources for the WebQuest fulfilment \\
\hline $\begin{array}{l}\text { Group } \\
\text { A }\end{array}$ & $\begin{array}{l}\text { to represent the types of } \\
\text { risks for engineers in the } \\
\text { workplace through the } \\
\text { offered by the educator } \\
\text { Internet websites; }\end{array}$ & $\begin{array}{l}\text { How can engineers stay safe in the workplace? - } \\
\text { https://www.nesgt.com/blog/2019/10/how-can-engineers- } \\
\text { stay-safe-in-the-workplace } \\
\text { Safety in Mechanical Engineering by Maureen Malone - } \\
\text { https://work.chron.com/safety-mechanical-engineering- } \\
\text { 27058.html }\end{array}$ \\
\hline $\begin{array}{l}\text { Group } \\
\text { B }\end{array}$ & $\begin{array}{l}\text { to describe protective } \\
\text { clothing and equipment } \\
\text { and their use by } \\
\text { engineers to perform all } \\
\text { kinds of work; }\end{array}$ & $\begin{array}{l}\text { Risk at Work - Personal protective equipment (PPE) } \\
\text { https://www.hse.gov.uk/toolbox/ppe.htm } \\
\text { PPE: Complete guide to Personal Protective Equipment } \\
\text { - https://www.shponline.co.uk/ppe-personal-protective- } \\
\text { equipment/ }\end{array}$ \\
\hline $\begin{array}{l}\text { Group } \\
\text { C }\end{array}$ & $\begin{array}{l}\text { to characterise measures } \\
\text { to be taken by engineers } \\
\text { to ensure their own } \\
\text { safety before, during } \\
\text { and after work; }\end{array}$ & $\begin{array}{l}\text { Seven ways to avoid potential safety hazards - } \\
\text { https://www.plantengineering.com/articles/seven-ways-to- } \\
\text { avoid-potential-safety-hazards/ } \\
\text { Hazard Prevention and Control a } \quad \text { and } \\
\text { https://www.osha.gov/shpguidelines/hazard-prevention.html }\end{array}$ \\
\hline
\end{tabular}

After finishing the WebQuest, the questionnaire was conducted to represent students' self-reflection, which, on the one hand, gave students the opportunity to evaluate the results of their own work on the WebQuest, and, on the other, helped them to determine the effectiveness of its use. The questions of the questionnaire were: 1) Were complicated texts presented on the proposed websites? 2) Was it easy or difficult to fulfil the WebQuest in a team? 3) What details / facts / information have you considered valuable for your future professional activity? 4) What has been learned in the course of the WebQuest? 5) What was interesting / boring during fulfilment of the WebQuest? 6) What has helped / hindered to fulfil the WebQuest? 7) Has this WebQuest improved your English proficiency as a matter of fact? 8) Has the vocabulary expanded in the course of the proposed WebQuest?

The survey results have shown that most students (over 70\%) noted the effectiveness of using a WebQuest technology when studying the topic "Health and safety".

Thus, in response to the question "Were complicated texts presented on the proposed websites?", the majority of respondents (over 59\%) answered that the previously analysed lexical material on the presented problem made it possible to understand almost completely the 
information presented in the WebQuest; $28 \%$ said that they used the dictionary to understand information accurately; $13 \%$ said that the material was difficult to understand.

When answering the question "Was it easy or difficult to fulfil the WebQuest in a team?", $54 \%$ of the respondents said that teamwork made their work easier and allowed them to perform the task better. About $24 \%$ of respondents indicated that they could work effectively both in a group and individually. $22 \%$ answered that they preferred to perform tasks independently.

When answering the question "What details / facts / information have you considered valuable for your future professional activity?", $29 \%$ of respondents said that they could replenish vocabulary with professionally oriented terminology, $46 \%$ said that they learned about a lot of types of hazards in the workplace and about ways to avoid them, expanded knowledge about protective equipment for engineers; $25 \%$

said they would be able to provide their own safety in the real world of production.

In response to the questions "What was interesting / boring during fulfilment of the WebQuest?" and "What has been learned in the course of the WebQuest?", most of the respondents (over 71\%) answered that the WebQuest was interesting and useful, especially with professionally oriented issues of the WebQuest, in particular, professionally oriented lexical material; 24\% said that the WebQuest was quite interesting but overburdened with tasks; $5 \%$ answered that they interested in information about different types of protective equipment.

When answering the question "What has helped / hindered to fulfil the WebQuest?", $58 \%$ of the respondents noted that they used the material they had previously completed while fulfilment the tasks of the WebQuest; $31 \%$ emphasized the opportunity to interact with the students of the group, to assist one another; $11 \%$ indicated that they could use additional materials (electronic dictionaries, textbooks, etc.). In response to the questions "Has this WebQuest improved your English proficiency as a matter of fact?" and "Has the vocabulary expanded in the course of the proposed WebQuest?", more than $80 \%$ of students said they had expanded their vocabulary significantly; $15 \%$ noted that they expanded their vocabulary; $5 \%$ was almost unchanged.

The results of the work on the WebQuest, as well as the questionnaire conducted, made it possible to find out that the WebQuest technology allows to significantly expand students' vocabulary on the topic, to interest and motivate them to study a particular problem, to intensify 
the study of professional terminology, to develop foreign-language lexical, socio-cultural and professionally oriented competences.

Conclusion. The analysis of advanced scientific researches, practical experience of implementing WebQuests in the educational process of Ukrainian technical institutions of higher education, as well as the results of students' questionnaire allowed to highlight the following advantages of this technology: presence of continuous feedback among all subjects of the educational process at all stages of completion of the WebQuest; possibility to use in the WebQuest authentic professionally oriented issues, modern materials and constant updating of the information presented in the WebQuest; increase of students' motivation and interest in studying, intensification of their educational and cognitive activity; development of students' foreign language lexical, socio-cultural and professionally oriented competences; stimulating students to self-education and success in learning activities, to self-improvement; applying a creative approach in the process of finding non-standard solutions to the tasks set in the WebQuest; developing teamwork skills and enabling all team members to feel responsible for their actions and the result of their work as a whole. The prospects for further scientific research include exploring the possibilities of integrating the WebQuest technology with other educational technologies, in particular information and communication, in order to obtain the highest possible result of students' foreign language training of Ukrainian technical institutions of higher education.

\section{References}

1. Hniedkova O. Pedahohichni umovy formuvannia kontroliu fakhovykh znan' maibutnikh uchyteliv inozemnykh mov u protsesi dystantsiinoho navchannia [Pedagogical conditions of formation of control of future foreign language teachers' professional knowledge in the process of distance learning]: dys. ... kand. ped. nauk: 13.00.04. Kherson. derzh. un-t. Kherson, 2017. 294 p.

2. Drobit I., Rak N. Efektyvnist vykorystannia avtentychnykh veb-resursiv u pidhotovtsi perekladachiv [Efficiency of using authentic web resources in translator training]. Informatsiini tekhnolohii i zasoby navchannia. 2013. Vol. 35. No. 3. P. 106-112.

3. Kankovskyi I. Ye. Web-kvest yak zasib aktyvizatsii samostiinoi roboty studentiv [WebQuest as a means of activating students' independent work]. Naukovyi zhurnal "Kompiuterno-intehrovani tekhnolohii: osvita, nauka, vyrobnytstvo". Vol. 11. Lutsk, 2013. P. 199-204.

4. Krasnopolskyi V. Inshomovna pidhotovka studentiv nefilolohichnykh spetsialnostei na osnovi stvorennia $i$ vykorystannia Web-tekhnolohii [Foreign language training for non- 
philological students based on the creation and use of Web-technologies]: dys. ... d-ra ped. nauk: 13.00.01 / Skhidnoukr. nats. un-t im. Volodymyra Dalia. Kyiv, 2019. 438 p.

5. Oliinychenko O. Osoblyvosti vykorystannia veb-kvest tekhnolohii u vykladanni anhliiskoi movy dlia spetsialnykh tsilei [Features of the usage of WebQuest technology for teaching English for specific purposes]. Naukovi zapysky. Seriia: Filolohichni nauky. 2019. Vol. 175. P. 889-893.

6. Pet'ko L.V. Imperativ globalizatsiynyh perspektyv - formuvannya profesiyno spryamovanogo inshomovnogo navchalnogo seredovischa $v$ umovah universitetu [The imperative of globalization perspectives - the forming of the professionally directed foreign language educational environment in the conditions of university]. Pedagogika vyshhoi' ta seredn'oi' shkoly: zb.nauk.prac' ; za red. Z.P.Bakum. Kryvoriz'kyj pedagogichnyj instytut DVNZ «Kryvoriz'kyj nacional'nyj universytet». Vol. 41. Kryvyj Rig : Drukarnja Romana Kozlova, 2014. P. 254-261.

7. Savchenko L. Vykorystannia veb-kvest tekhnolohii u vyshchii shkoli pry pidhotovtsi maibutnikh fakhivtsiv [The use of WebQuest technologies in higher education in the preparation of future specialists]. Pedahohika vyshchoi ta serednoi shkoly. 2017. Vol. 1 (50). P. 67-74.

8. Slyusarenko N., Kulbatska M. (Soter M.). Teoretychni aspekty formuvannia u studentiv umin $i$ navychok mizhkulturnoho spilkuvannia pry vyvchenni inozemnoi movy [Theoretical aspects of formation of students' intercultural communication skills in the process of foreign language studying]. Pedahohichnyi almanakh. Kherson : KVNZ «KhANO», 2015. Vol. 27. P. 109-116.

9. Slyusarenko N., Lipshyts L. Formuvannia sotsiokulturnoi osobystosti maibutnoho sudnovodiia na zasadakh kompetentnisnoho pidkhodu [Formation of the sociocultural personality of future navigators on the basis of competence approach]. Liudynoznavchi studii. Seriia: Pedahohika. 2014. Vol. 1 (29). P. 173-181.

10. Slyusarenko N. V., Soter M. V. Problemy movnoi pidhotovky v tekhnichnykh zakladakh vyshchoi osvity Ukrainy (pochatok XXI stolittia) [Problems of language training in technical institutions of higher education of Ukraine (beginning of the 21st century)]. Teoretykometodolohichni osnovy rozvytku osvity ta upravlinskoi diialnosti: mat. V Vseukr. nauk.-prakt. konf. (12-13 veresnia 2019 r., m. Kherson) Kherson: KVNZ "Khersonska akademiia neperervnoi osvity", 2019. P. 183-186.

11. Bernie Dodge. Some Thoughts About WebQuests. San Diego State University. 2005. URL: https://jotamac.typepad.com/jotamacs_weblog/files/WebQuests.pdf

12. Pet'ko L.V. Development of students' cognitive activity in foreign language teaching by using analogy method // Actual problems of globalization: Collection of scientific articles. Midas S.A., Thessaloniki, Greece, 2016. P. 232-237.

13. Pet'ko L.V. The formation of professionally oriented foreign language teaching environment for Math students in the conditions of university // Prospects for development of education and science: Collection of scientific articles. - Academic Publishing House of the Agricultural University Plovdiv, Bulgaria, 2016. P. 352-356. 
Translation of the Title, Abstract and References to the Author's Language

\section{УДК 378.141}

Слюсаренко Ніна, Сотер Марія. Веб-квест як засіб підвищення ефективності іншомовної підготовки студентів технічних закладів вищої освіти України (початок XXI ст.).

Виявлено можливості технології веб-квест щодо підвищення ефективності іншомовної підготовки студентів технічних закладів вищої освіти України на початку XXI століття. Зазначено, що можливість через веб-квест залучати різного роду автентичні тексти 3 професійно-орієнтованою проблематикою допомагає підвищити мотивацію студентів до навчання та досягнення професійних цілей, дає можливість активізувати їх пізнавальну діяльність та посилити прагнення до самоосвіти. Представлено переваги цієї технології щодо поліпшення іншомовної підготовки студентів. Наведено результати анкетування, які підтверджують, що технологія веб-квест дозволяє розширити словниковий запас студентів із певної теми, зацікавити й вмотивувати їх до вивчення тієї чи іншої проблеми, активізувати процес вивчення професійно-орієнтованої термінології, розвинути іншомовну, лексичну, соціокультурну та професійно орієнтовану компетентності студентів.

Ключові слова: технологія веб-квест, ресурси мережі Інтернет, іншомовна підготовка студентів, технічні заклади вищої освіти України.

\section{Лimepamypa}

1. Гнєдкова О. Педагогічні умови формування контролю фахових знань майбутніх учителів іноземних мов у процесі дистанційного навчання: дис. ... канд. пед. наук: 13.00.04 / Херсон. держ. ун-т. Херсон, 2017. 294 с.

2. Дробіт I., Рак Н. Ефективність використання автентичних веб-ресурсів у підготовці перекладачів. Інформаційні технології $і$ засоби навчання. 2013. Т. 35. № 3. C. $106-112$.

3. Каньковський I. Web-квест як засіб активізації самостійної роботи студентів. Комп'ютерно-інтегровані технологї: освіта, наука, виробництво. 2013. Вип. 11. C. 199-204.

4. Краснопольський В. Е. Іншомовна підготовка студентів нефілологічних спеціальностей на основі створення і використання Web-технологій: дис. ... д-ра пед. наук: 13.00.01 / Східноукр. нац. ун-т ім. Володимира Даля. Київ, 2019. 438 с.

5. Олійниченко О. Особливості використання веб-квест технології у викладанні англійської мови для спеціальних цілей. Наукові записки [Центральноукраӥнського державного педагогічного університету імені В. Винниченка]. Серія: Філологічні науки. 2019. Вип. 175. С. 889-893.

6. Петько Л.В. Імператив глобалізаційних перспектив - формування професійно спрямованого іншомовного навчального середовища в умовах університету. Педагогіка вищої та середньої школи: зб.наук.праць ; за ред. З.П.Бакум. Криворізький пед. інститут ДВНЗ «Криворізький національний університет». Вип. 41. Кривий Ріг : Друкарня Романа Козлова, 2014. С. 254-261.

7 Савченко Л. Використання веб-квест технологій у вищій школі при підготовці майбутніх фахівців. Педагогіка вищзої та середньої школи. 2017. Вип. 1 (50). С. 67-74. 
8. Слюсаренко Н., Кульбацька М. (Сотер М.). Теоретичні аспекти формування у студентів умінь і навичок міжкультурного спілкування при вивченні іноземної мови. Педагогічний альманах. Херсон: КВНЗ «ХАНО», 2015. Вип. 27. С. 109-116.

9. Слюсаренко Н., Ліпшиць Л. Формування соціокультурної особистості майбутнього судноводія на засадах компетентнісного підходу. Людинознавчі студіï. Серія: Педагогіка. Дрогобич: ДДПУ ім. Івана Франка, 2014. Вип. 1 (29). С. 173-181.

10. Слюсаренко Н., Сотер М. Проблеми мовної підготовки в технічних закладах вищої освіти України (початок XXI століття) / Теоретико-методологічні основи розвитку освіти та управлінської діяльності: мат. V Всеукр. наук.-практ. конф. (12-13 вересня 2019 р., м. Херсон) / за ред. Кузьменка В., Слюсаренко Н.: у ІІ ч. Ч. ІІ. Херсон: КВНЗ «Херсонська академія неперервної освіти», 2019. С. 183-186.

11. Bernie Dodge. Some Thoughts About WebQuests. San Diego State University. 2005. URL : https://jotamac.typepad.com/jotamacs_weblog/files/WebQuests.pdf

12. Pet'ko L.V. Development of students' cognitive activity in foreign language teaching by using analogy method // Actual problems of globalization: Collection of scientific articles. Midas S.A., Thessaloniki, Greece, 2016. P. 232-237.

13. Pet'ko L.V. The formation of professionally oriented foreign language teaching environment for Math students in the conditions of university // Prospects for development of education and science: Collection of scientific articles. - Academic Publishing House of the Agricultural University Plovdiv, Bulgaria, 2016. P. 352-356. 